\title{
FACTORS RELATED TO DISCLAIMER ATTITUDES TO PEOPLE WITH HIV AND AIDS (PLWHA)
}

\author{
Dian Ayu Lestari \\ Faculty of Public Health, Universitas Airlangga, 60115 Surabaya, East Java, Indonesia \\ Corresponding Author: Dian Ayu Lestari \\ E-mail: dian.ayu.lestari-2016@fkm.unair.ac.id
}

\begin{abstract}
HIV/AIDS remain the most serious diseases worldwide. One of the efforts that health workers have made in health promotion using prevention and control. This study aims to determine the factors that interact with the attitude of PLWHA. This study used a descriptive analysis using the chi-square statistical test. The use of data is secondary data from 2017 Indonesian Demographic and Health Survey (IDHS). The results of statistical testing using the chi-square found that the factors that influence rejection attitudes in people with HIV/AIDS (PLWHA) are age (p $=0.001 ; \lambda=0,05)$, area of residence $(\mathrm{p}=0.001 ; \lambda=0.05)$, education $(\mathrm{p}=0.001 ; \lambda=0.05)$, and exposure to mass media $(\mathrm{p}=0.001 ; \lambda=0.05)$. From the results of statistical tests, it can be seen that attitudes towards PLWHA are influenced by age and area of residence.
\end{abstract}

Keywords: Human Immunodeficiency Virus/Acquired Immune Deficiency Syndrome, People with Human Immunodeficiency Virus / Acquired Immune Deficiency Syndrome, rejection

\begin{abstract}
ABSTRAK
HIV dan AIDS tetap sebagai penyakit paling serius di seluruh dunia. Salah satu upaya yang telah dilakukan tenaga kesehatan adalah promosi kesehatan cara pencegahan dan pengendalian. Penelitian ini bertujuan mengetahui faktor yang berinteraksi dengan sikap ODHA. Penelitian ini menggunakan analisis deskriptif dengan memakai uji statistik chi square. Penggunaan data yaitu data sekunder hasil Survey Demografi dan Kesehatan Indonesia (SDKI) tahun 2017. Hasil pengujian statistik menggunakan chi square didapatkan bahwa faktor yang mempengaruhi sikap penolakan pada orang dengan HIV dan AIDS (ODHA) yaitu usia $(p=0,001 ; \lambda=0,05)$, daerah tempat tinggal ( $p=0,001 ; \lambda=0,05)$, pendidikan $(p=0,001 ; \lambda=0,05)$, dan keterpaparan media massa $(p$ $=0,001 ; \lambda=0,05)$. Dari hasil uji statistika dapat dilihat bahwa sikap terhadap ODHA dipengaruhi usia, daerah tempat tinggal, pendidikan, serta keterpaparan media massa sehingga masyarakat harus lebih diberi sosialisasi tentang HIV dan AIDS agar tidak lagi yang mendeskriminatif individu yang menderita HIV dan AIDS.
\end{abstract}

Katakunci: Human Immunodeficiency Virus/Acquired Immune Deficiency Syndrome, Orang dengan Human Immunodeficiency Virus/Acquired Immune Deficiency Syndrome, penolakan

Received: July 15, 2020

Accepted: August 08, 2020

\section{INTRODUCTION}

Since the beginning of the epidemic in Indonesia and even the world, Human Immunodeficiency Virus (HIV) is a severe health sector problem. Efforts that have been made by the government in dealing with HIV/AIDS health problems, especially in the negative stigma of society towards PLWHA, include health promotion by health workers (Permenkes RI, 2013). Rejection is a form of stigma that leads to prejudice, negative attitudes, and rejection of people living with HIV/AIDS (PLWHA) to the people concerned with PLWHA.
A total of 37.9 million people in the world are affected by HIV/AIDS (PLWHA). Meanwhile, there were 3.8 million people affected by HIV/AIDS in the East and South Asia region. This situation is the secondhighest-ranking after the African continent (WHO, 2018). Indonesia itself ranks third after India and China, which amounted to (18\%) many new HIV/AIDS incidents in 2017 (UNAIDS, 2018). Meanwhile, deaths caused by HIV/AIDS in Indonesia increased (68\%) (UNAIDS, 2017). Based on the level of the HIV epidemic, the greatest prevalence was East Java, with a rate of $24.52 \%$ (Nugroho, 2019). 
There is a difference in the number of HIV/AIDS cases based on sex, namely that the male sex has several 348 greater than female PLWHA by 180 (Harjono, 2018). A survey in Asian countries said that $80 \%$ of respondents accepted an attitude of opposition and discrimination, including health (54\%), association (30\%), family (18\%), and place employment (18\%) (UNAIDS, 2011).

An observation conducted by Oktarina regarding the attitudes of Indonesian society about people with PLWHA said that the majority of respondents or the Indonesian people showed negative or rejecting attitudes about PLWHA (62.7\%) and that showed positive or accepting attitudes (37\%) (Oktarina, 2012). In life in society, there are many groups of groups that can cause differences in various things, such as place of residence, level of education, social position, and so on, leading to a creative attitude in society. The discriminatory actions that individuals and groups in the community have received have increased very widely. One of the discriminatory acts vulnerable to being experienced is the group of people with HIV/AIDS (PLWHA) (Wisnu, 2017).

One factor regarding rejection behavior towards people with HIV/AIDS is knowledge (Constantine, 2017). Knowledge of HIV/AIDS dramatically influences people's behavior towards HIV/AIDS (Shaluhiyah, 2015). Poor knowledge and attitudes of Indonesian society regarding people with HIV/AIDS (PLWHA) can harm HIV/AIDS prevention and control programs and the standard of life of these sufferers. Individuals with HIV/AIDS will feel afraid of taking an HIV test because if the results show HIV positive, it will cause them to be isolated by the surrounding community. Meanwhile, people who are HIV positive will feel afraid to say their HIV status and will delay treatment such as feeling sick, so that this will have a negative impact or decreased health levels in people with HIV/AIDS, and the transmission is uncontrolled.

Attempts to dispel attitudes and discrimination concerning people with HIV/AIDS need to be implemented to emphasize the rate of increase in HIV/AIDS. One way is to carry out socialization about HIV/AIDS to the community, which aims to increase their knowledge and awareness of those who are still poor/insufficient. This is very important to do, namely changing society's negative mindset related to HIV/AIDS to individuals with HIV/AIDS. The participation of figures/parties who are very influential in society is also essential for inviting the community to eliminate hostile rejection and discrimination attitudes PLWHA.

The purpose of this observation is to see what factors change the attitude of rejection of PLWHA. This observation is expected to help stakeholders, especially the government, provide broad knowledge and insight to the Indonesian people about HIV/AIDS through socialization.

\section{METHODS}

This study used an observational method based on the 2017 IDHS data source. The research design used was a cross-sectional method. The population of observations required was all individuals who were not PLHIV from the 2017 IDHS data. The number of respondents was 21617 using 3-stage multistage random sampling. The representative population used is part of the population with a benchmark that is comparable to the research target and completes the required variables

This research technique uses secondary data IDHS from the year 2017 by using a storage strategy. Data IDHS 2017 obtained from the website Demography Health Survey (DHS) (2017).

Statistic analysis that used is an examination of the interaction between the independent variable is age (the length of life of an individual from birth to data collection in units of years) the category used is the age 15 to 49 , the second is the area of residence (type of area where the respondent lives) the categories used are urban and rural, the third level of education (individuals took the last formal education) the categories used are no school, elementary school, junior high school, senior high school, the fourth is exposure to mass media (the number of mass media used by respondents to find out information about HIV/AIDS) the categories used were often received information and rarely received information. The previous knowledge (everything that is known, including what the respondent hears, sees, and reads about HIV/AIDS, including the meaning of HIV/AIDS, how it is transmitted, and how to prevent it) the categories used are excellent and 
imperfect. While the dependent variable is the attitude towards PLWHA (or negative or positive attitudes carried out by the community towards PLWHA), the categories used are rejecting and accepting. Testing these variables using the test Chi-square. The test aims to see the interaction variables that have been observed using the $95 \%$ confidence limit. A review of the data displayed is in the form of a table and an explanation.

In this category of exposure is divided into two categories, namely often obtaining information and rarely receiving information. The information exposure score about HIV/AIDS through radio, television, newspapers, posters, religious associations, schools, associations, friends, health workers, workplaces, and the internet. Each media gets a score of 1 , so the score for all media $=11$. If you don't answer, all of them will get a score of 0 . This categorization is done through the maximum score minus the minimum score, divided into two categories: frequent exposure and rarely exposed. It is said that they are often exposed to the media if the score is more than or equal to 6 . It is said that they are rarely exposed to the media if the score is less than 6 . The attitude variable towards PLWHA, yes, no, and don't know answers, rejects with a score (0-2) and accepts (3-4). While the knowledge variable has the answers to yes, no, and don't know, to facilitate the data processing, this variable is divided into two categories, namely bad with score (0-4) and good (5-9).

\section{RESULT}

\section{Specific General Respondents}

Table 1. describe the specifics general respondents, namely age, education lastly, and the area of residence. Table 1 . shows that very many respondents there a distribution interval age $16-20$ years show as much as 3637 (6.8\%); meanwhile, frequency respondents total the smallest areas on age group <15 years, namely some 597 respondents or $2.8 \%$. Place area Live respondents indicated that 13510 respondents $(62.5 \%)$ were domiciled in urban areas while 8107 respondents (37.5\%) live in rural areas. For education categories, Indonesians mostly graduated from junior high school with a figure of $12914(59.7 \%)$, and only 49 respondents $(0.2 \%)$ did not attend a school or did not attend school.

Table 1. Specific General Respondents

\begin{tabular}{lcr}
\hline & $\begin{array}{c}\text { amount } \\
(\mathbf{n = 2 1 6 1 7})\end{array}$ & $(\boldsymbol{\%})$ \\
\hline Age & & \\
\hline$<15$ & 597 & $2.8 \%$ \\
$16-20$ & 3637 & $16.8 \%$ \\
$21-25$ & 3514 & $16.3 \%$ \\
$26-30$ & 3183 & $14.7 \%$ \\
$31-35$ & 3282 & $15.2 \%$ \\
$36-40$ & 3069 & $14.2 \%$ \\
$41-45$ & 2664 & $12.3 \%$ \\
$>45$ & 1671 & $7.7 \%$ \\
\hline Residence Area & & \\
\hline Urban & 13510 & $62.5 \%$ \\
Rural & 8107 & $37.5 \%$ \\
\hline Level of education & & \\
\hline Never school & 49 & $0.2 \%$ \\
Elementary school & 2835 & $13.1 \%$ \\
Junior High school & 12914 & $59.7 \%$ \\
High school & 5819 & $26.9 \%$ \\
\hline
\end{tabular}

\section{Characteristics of Mass Media Exposure to HIV/AIDS}

Table 2 shows an overview concerning mass media exposure to HIV/AIDS according to the 2017 IDHS questionnaire. Based on the 2017 IDHS data, most Indonesians are rarely exposed to mass media, with a figure of 13729 or $63.5 \%$. This is because respondents are only exposed to three media from several media such as radio, television, newspapers, posters, religious associations, schools, associations, friends, health workers, places work, internet.

\section{Characteristics of Indonesian Public Knowledge about HIV/AIDS}

Table 2 shows an overview of knowledge about HIV/AIDS. Respondents as a community about knowledge about HIV/AIDS according to the 2017 IDHS questionnaire. The Indonesian people's knowledge shows that most Indonesian people have insufficient knowledge of HIV/AIDS, with 13721 or $63.5 \%$.

\section{Attitude Characteristics of Person With HIV/AIDS}

Table 2 shows the picture about attitudes towards people with HIV/AIDS according to the 2017 IDHS questionnaire. 
From these two categories, most Indonesians reject the existence of people with HIV/AIDS with a figure of 15259 or $70.6 \%$.

Table 2. Characteristics of Indonesian Society Related to Mass Media Exposure, Knowledge, Attitudes Toward PLWHA

\begin{tabular}{lcc}
\hline $\begin{array}{l}\text { Mass Media } \\
\text { Exposure }\end{array}$ & Frequency & $\mathbf{( \% )}$ \\
\hline Less exposed & 13729 & $63.50 \%$ \\
Exposed & 7888 & $36.50 \%$ \\
\hline Knowledge & Frequency & $\mathbf{( \% )}$ \\
\hline Good & 7896 & $36.50 \%$ \\
Bad & 13721 & $63.50 \%$ \\
\hline Attitudes & Frequency & \\
towards & & $(\boldsymbol{\%})$ \\
PLWHA & & \\
\hline Reject & 15259 & $70.60 \%$ \\
Receive & 6358 & $29.40 \%$ \\
\hline
\end{tabular}

Relation of Occupied Area, Exposure Media Mass, Knowledge, Age, and Education Level with Attitude To PLWHA

The bivariate test is carried out Chisquare statistical test on all variables for know the top interactions dependent variable that is rejection attitude towards PLWHA. Table 3 shows the interactions Among area the place Live respondents, mass media exposure, and knowledge.

The residence variable location gets a p-value of 0.000 ; it can be concluded that $\mathrm{H} 0$ is not accepted. It means that the area of residence has an interaction with the attitude of rejection of PLWHA. On the mass media exposure variable getting a p-value of 0,000 , it can be concluded that $\mathrm{HO}$ is not accepted, meaning that exposure to mass media has an interaction with resistance to PLWHA.

The knowledge variable gets a p-value of 0.000 , so it can be concluded that $\mathrm{H} 0$ is not accepted, meaning that knowledge interacts with the attitude of rejection of PLWHA. The age variable gets a p-value of 0,000 ; it can be concluded that $\mathrm{HO}$ is not accepted, meaning that age interacts with the attitude of rejection towards PLWHA.
The education variable gets a value $p$ amounting to 0,000 ; it can be concluded that $\mathrm{H} 0$ is not accepted, meaning that the level of education interacts with the attitude of rejection of PLHIV.

\section{DISCUSSION}

Factors in terms of age, education, area of residence, knowledge, and exposure to mass media, these factors have a positive correlation with the discriminatory attitudes of PLWHA.

In line with Baroyah's research, the aging study also shows that the respondent's age is closely related to the attitude of rejection of HIV/AIDS, as evidenced by a p-value of 0.022 (Baroyah, 2017). In line with Baroyah, Amelia's research also shows that the respondent's age is closely related to the rejection of HIV/AIDS, given a p-value of 0.050 (Amelia, 2016).

The research results regarding the level of education are research evidence that Rahmayani had researched, resulting in a pvalue of 0.040 . The $p$ number is known the results are unidirectional or positive ones the meaning is their interaction Among level education with opposing behavior towards people with HIV/AIDS (Rahmayani, 2014). Another study conducted by Haryanti also showed a p-value of 0.015 . The $p$ number is known the results are unidirectional or positive ones the meaning is there interaction Among level education with opposing behavior towards people with HIV/AIDS (Haryanti, 2019).

Research on the residence is in line with Wahyuni's study, resulting in a p-value of 0.000 . At this $p$ number, it is known that the results do not exceed the limit of trust, which means that there is a very close relationship regarding the domicile of residence with opposing behavior towards people with HIV/AIDS (Wahyuni, 2017). However, in contrast to the study results by Tiranda, this study resulted in a p-value of 1,000 . At this $\mathrm{p}$ number, it is known that the result exceeds the limit of trust, which means that there is no very close relationship regarding the domicile of residence with opposing behavior towards people with HIV/AIDS (Tiranda, 2018). 
Table 3. Results of the community Chi-square test based on the area occupied, the mass media used, knowledge, age, and level of education regarding the attitudes given to PLWHA

\begin{tabular}{|c|c|c|c|c|c|}
\hline \multirow{3}{*}{ Variable } & \multicolumn{4}{|c|}{ Attitudes towards PLWHA } & \multirow{3}{*}{$\boldsymbol{P}$} \\
\hline & \multicolumn{2}{|c|}{ Reject } & \multicolumn{2}{|c|}{ Receive } & \\
\hline & $\mathbf{n}$ & $\%$ & $\mathbf{n}$ & $\%$ & \\
\hline Residence Area & & & & & 0,000 \\
\hline Urban & 9207 & $60.30 \%$ & 4303 & $67.70 \%$ & \\
\hline Rural & 6052 & $39.70 \%$ & 2055 & $32.30 \%$ & \\
\hline Mass Media Exposure & & & & & 0,000 \\
\hline Less Exposure & 10023 & $65.70 \%$ & 3706 & $58.30 \%$ & \\
\hline Exposed & 5236 & $34.30 \%$ & 2652 & $41.70 \%$ & \\
\hline Knowledge & & & & & 0,000 \\
\hline Good & 6307 & $41.30 \%$ & 1589 & $25 \%$ & \\
\hline $\mathrm{Bad}$ & 8952 & $58.70 \%$ & 4769 & $75 \%$ & \\
\hline Age & & & & & 0,000 \\
\hline$<15$ & 444 & $2.90 \%$ & 153 & $2.40 \%$ & \\
\hline $16-20$ & 2490 & $16.30 \%$ & 1147 & $18 \%$ & \\
\hline $21-25$ & 2491 & $16.30 \%$ & 1023 & $16.30 \%$ & \\
\hline $26-30$ & 2208 & 14.55 & 975 & $15.30 \%$ & \\
\hline $31-35$ & 2302 & $15.10 \%$ & 980 & $15.40 \%$ & \\
\hline $36-40$ & 2123 & $13.90 \%$ & 946 & $14.90 \%$ & \\
\hline $41-45$ & 1951 & $12.80 \%$ & 713 & $11.20 \%$ & \\
\hline$>45$ & 1250 & $8.20 \%$ & 421 & $6.60 \%$ & \\
\hline Level of education & & & & & 0,000 \\
\hline Never school & 47 & $0.30 \%$ & 2 & $0.00 \%$ & \\
\hline Elementary school & 2173 & $14.20 \%$ & 662 & $10.40 \%$ & \\
\hline Junior High school & 9290 & $60.90 \%$ & 3624 & $57 \%$ & \\
\hline High school & 3749 & $24.60 \%$ & 2070 & $32.60 \%$ & \\
\hline
\end{tabular}

Research regarding the relationship between mass media exposure and rejection agrees with research Liawati, where the value of $\mathrm{p}$ a number of 0.053 . The result of the value $\mathrm{p}$ value is not beyond the limit of trust. There is a relationship between mass media exposure and behavior opposition to people with HIV/AIDS (Liawati, 2018). The research also agrees with Setiyawati's study, which results in p-value a number of 0.045 . The result of the value $p$-value is not beyond the limit of trust. There is a relationship between mass media exposure and behavior opposition to people with HIV/AIDS (Setiyawati N, 2015).

In the study of the relationship between knowledge and rejection of PLWHA, it was proven in Priastana's research which produced a p-value of 0.001 . This figure shows the rejection of attitudes to have a relationship with the knowledge possessed by the community, because it does not pass Interva 1 trust (Priastana, 2018). The same research was conducted by Situmeang (2017), which shows that knowledge is closely related to the attitude of rejection of people with HIV / AIDS, resulting The value of $p$ does not exceed the limit of trust, it means that knowledge is related to the attitude of rejection. Meanwhile, according to research from Ima Kharimaturrohmah, it also shows a relationship between knowledge and rejection of people with HIV/AIDS as evidenced by the chi square test which results in a $\mathrm{p}$ value of 0.001 (Kharimaturrohmah, 2012).

The high rejection of PLWHA in the 16-20 year age group may occur because they are still in the adolescent category at that age, which means that knowledge about HIV/AIDS is still lacking. The high rejection of PLHIV in the low-educated group probably occurs because there are education levels, so the higher the education, the more ideas are obtained and vice versa. The high rejection of PLHIV in groups less exposed to the mass media is likely due to the public's lack of enthusiasm towards mass media, especially mass media that discuss HIV/AIDS. Some people do not know about HIV/AIDS. The high rejection of people living 
with HIV in the poor knowledge group is likely due to the lack of education and socialization about HIV/AIDS by the government and health workers. The high rejection of people living with HIV in the group with rejection attitudes probably occurs because of the negative stigma about people living with HIV/AIDS, making people reluctant to socialize with people living with HIV/AIDS.

\section{CONCLUSIONS AND SUGGESTIONS}

\section{Conclusions}

The above research concluded that most respondents or the Indonesian people had a high rejection attitude towards people with HIV/AIDS. This condition is influenced by inadequate knowledge, lack of exposure to mass media, place of residence, age, and education.

\section{Suggestion}

It was found that people living in urban areas showed rejection of PLHAs, so health workers and community leaders had to work together to promote health about HIV/AIDS in every citizen living in urban areas.

In mass media exposure, the majority are not exposed to the mass media, so they show rejection for PLHAs. The government and health workers must cooperate to promote health regarding HIV/AIDS through mass media that individuals widely use.

In the educator variable, it is known that low education affects resistance to PLHAs so that the government must provide facilities and oblige minimum education to high school level so that public knowledge is broader. On the other hand, health workers must often educate every citizen about HIV/AIDS so that there is no more discrimination against PLHAs.

In the knowledge variable, it is known that lousy knowledge affects the attitude of resistance to PLHAs, so the role of the government and health workers is needed because people with inadequate knowledge need to be educated through equitable socialization to the Indonesian people about HIV/AIDS.

\section{REFERENCES}

Amelia M., Hadisaputro S., Laksono B., Anies., And Sofro M., AU., 2016. Risk Factors Influencing the Incidence of HIV /
AIDS in Men Age 25 - 44 Years in Dili, Timor Leste. Journal of Community Health Epidemiology, 1 (1), pp. 39-46. Baroyah, N., 2017. Predictors of Stigma and Discrimination Against People with HIV/AIDS (PLWHA) in Jember Regency. IKESMA Journal, 13 (2), pp. 117-126.

Harjono, AE, K., 2018. Comparison of Forecasting Results of the Number of HIV Cases by Gender in Malang City with the Exponential Smoothing Method. Journal of Biometrics and Population, 6 (1), pp. 9-16.

Haryanti Titik, W., 2019. Perception of people living with HIV / AIDS on social stigma of HIV / AIDS in Sukoharjo District. Kesmas, 13 (3), pp. 132-137.

Kharimaturrohmah, I. and Shaluhiyah, Z., 2012. The Influence of the Attitudes of Friends and Parents to the Stigma of PLWHA by Nursing Students of STIKes Yogyakarta City. Indonesian Journal of Health Promotion, 8 (2), pp. 131-139.

Liawati, 2018. Factors Influencing HIV / AIDS Prevention Behavior in Commercial Sex Workers (CSWs) in Bandung in 2017. Midwife Journal "Midwife Journal", 4 (02), pp. 25-35.

Nugroho, DY, WA, 2019. Cluster K-Means Analysis of the Hiv Epidemic Level in the Cities of East Java. Journal of Biometrics and Population, 8 (2), pp. 109-119.

Oktarina., Hanafi, F. and and Budisuari, M., A., 2012. The Relationship Between Respondent Characteristics, Regional Conditions with Knowledge, Attitudes Toward HIV / AIDS in Indonesian Society. Health Systems Research Bulletin, 12 (4), pp. 362-369.

Permenkes RI, 2013. Regulation of the Minister of Health of the Republic of Indonesia No.21 of 2013 concerning HIV/AIDS Prevention. Jakarta: Ministry of Law and Human Rights.

Priastana IKA, and SH, 2018. The Relationship between Knowledge Levels of HIV / AIDS and Attitudes to Prevent HIV / AIDS in Adolescents. Indonesian Journal of Health Research, 1(1), pp.1-5.

Rahmayani V., Hanif, AM, SS, 2014. Relationship of Knowledge and 
Attitude with Prevention of HIV-AIDS Transmission in Transgenders in Padang City, 2013. Andalas Health Journal, 3 (2), pp.238-243.

Setiyawati N., Meilani N., 2015. Determinant of HIV Testing Behavior among Pregnant Women. National Society Health, 8(3), pp. 201-206.

Shaluhiyah, Z., Musthofa, SB and and Widjanarko, B., 2015. Community stigma against people living with HIV / AIDS. Kesmas: National Public Health Journal, 9 (4), pp. 333-339.

Situmeang, B., Syarif, S. and Mahkota, R., 2017. The Relationship between HIV / AIDS Knowledge and Stigma against People with HIV / AIDS among Youths 15-19 Years in Indonesia (2012 IDHS Data Analysis). Indonesian Journal of Health Epidemiology, 1 (2), pp. 35-43.

Sudikno, Simanungkalit B., and S., 2011. Knowledge of HIV/AIDS in Adolescents in Indonesia. Journal of Reproductive Health, 1 (3), pp. 145154.

Tiranda M., Setiyawati N., and Rahmawati A., 2018. Family Support as a Factor Influencing Exclusive Breastfeeding for Adolescent Mothers in Bantul,
Yogyakarta. Accreditation Number: Public Health Journal, 12 (3), pp. 114119.

UNAIDS, 2011. People Living with HIV Stigma Index in Asia Pacific Regional. 2011th ed. [online] Available at: <https://www.unaids.org/>.

UNAIDS, 2017. UNAIDS Data 2017. [online] Program on HIV / AIDS. Available at: <https://www.unaids.org/ >.

UNAIDS, 2018. UNAIDS Data 2018. [online] Available at: <https://www.unaids.org/ >.

Wahyuni, AS, and RS, 2017. The Relationship Between HIV / Aids Knowledge and Rejection of People With HIV / AIDS (PLWHA) in Indonesian Society (Further Analysis of 2012 Indonesian Demographic and Health Survey). Journal of Reproductive Health, 8 (1), pp. 41-52.

WHO, 2018. HIV / AIDS. [online] World Health Organization. Available at: <https://www.who.int/hiv/data/en/>

Wisnu, MA, 2017. Discrimination of People With HIV / Aids (PLWHA). Sunan Kalijaga State Islamic University, Yogyakarta. 